\title{
CHARACTERIZATION AND HYDRATION REACTIVITY OF $\alpha$-TRICAICIUM PHOSPHATE PREPARED BY HEATING WITH GYPSUM
}

\author{
Hideki Monma $^{1}$, Yusuke Moriyoshi ${ }^{1}$, Hironori Ogata ${ }^{1}$, Toshinori Okura ${ }^{2}$ \\ (*Corresponding author: hideki.momma.72@hosei.ac.jp)
}

\author{
${ }^{1}$ Res. Center for Micro-Nano Technology, Hosei University, 3-11-15 Midori-cho, Koganei-shi, \\ Tokyo 184-0003, Japan \\ ${ }^{2}$ Faculty of Engineering, Kogakuin University, 2665 Nakano-cho, Hachioji-shi, \\ Tokyo 192-0015, Japan
}

Keywords: Gypsum, Tricalcium phosphate, Hydration reactivity

\begin{abstract}
Beta tricalcium phosphate $\left(\beta-\mathrm{Ca}_{3}\left(\mathrm{PO}_{4}\right)_{2}, \beta-\mathrm{TCP}\right)$ mixed with gypsum $\left(\mathrm{CaSO}_{4} \cdot 2 \mathrm{H}_{2} \mathrm{O}\right)$ was heated at $1300^{\circ} \mathrm{C}$ and $1400^{\circ} \mathrm{C}$. The resulting products were characterized by DTA, XRD, FTIR, EDX and hydration reactivity. An inhibition effect on the transition of the low temperature form $\beta$ to high temperature form $\alpha$ was observed with increasing the amount of gypsum. The substitution of $\mathrm{SO}_{4}$ for $\mathrm{PO}_{4}$ was suggested from increases of the $\beta \rightarrow \alpha$ transition temperature and hydration reactivity. However both the substitution and the presence of $\mathrm{S}$ were not recognized by XRD, EDX and FTIR. Increasing the amount of gypsum resulted in the formation of hydroxyapatite $\left(\mathrm{Ca}_{5}(\mathrm{OH})\left(\mathrm{PO}_{4}\right)_{3}\right)$ at $1300^{\circ} \mathrm{C}$ and tetracalcium phosphate $\left(\mathrm{Ca}_{4}\left(\mathrm{PO}_{4}\right)_{2} \mathrm{O}\right)$ at $1400^{\circ} \mathrm{C}$. The hydration reactivity was in the order, pure $\alpha$-TCP $<<\alpha$-TCP heated with gypsum.
\end{abstract}

(Received Oct. 6, 2011; Accepted March 17, 2012)

\section{INTRODUCTION}

Tricalcium phosphate $\left(\mathrm{Ca}_{3}\left(\mathrm{PO}_{4}\right)_{2}\right.$, referred to as TCP) has two polymorphs named low temperature form $\beta$ and high temperature form $\alpha$. The transition temperature is $c a .1180^{\circ} \mathrm{C}$. $\beta$-TCP ceramics is applied to artificial bone substitute. Whereas $\alpha$-TCP powder is a basic material for making bone cements using its unique chemical property, i.e., hydrationhardening. Powdery $\alpha$-TCP is easily prepared by rapid cooling from temperatures above the transition temperature. On the other hand, the preparation of $\beta$-TCP bulk ceramics had a certain difficulty because temperatures for its sintering are generally required to be higher than the transition temperature. So, many studies on increasing the transition temperature have been done for producing $\beta$-TCP ceramics. For instance, the inhibiting effect of the substitution of $\mathrm{Mg}^{2+}$ and $\mathrm{Al}^{3+}$ for $\mathrm{Ca}^{2+}$ on the $\beta \rightarrow \alpha$ transition is well-known to be remarkable. The dissolving limit of $\mathrm{Mg}$ into $\beta$-TCP have been reported to be around $13.6^{1}$ in $\mathrm{Mg} /(\mathrm{Ca}+\mathrm{Mg}) \mathrm{mol} \%$ at $1000^{\circ} \mathrm{C}$, and $13.2^{2}$ at $1175^{\circ} \mathrm{C}$. Hashimoto et al. clarified the conditions for the precipitation of whitlockite $6 \mathrm{Ca}_{3}\left(\mathrm{PO}_{4}\right)_{2} \cdot 2 \mathrm{MgHPO}_{4}$ from aqueous solution, and studied in detail on its heated product, i.e., $\mathrm{Mg}$-containing $\beta$ - $\mathrm{TCP}{ }^{3,4}$. With the dissolution of $\mathrm{Mg}^{2+}$ into the $\beta$-TCP structure, the lattice constants became contracted, and the $v_{3}$ stretching infrared spectroscopic (IR) bands assigned to $\mathrm{PO}_{4}$ showed a blue-shift and splits due to a lowering of the symmetry of $\mathrm{PO}_{4}{ }^{5}$.

On the other hand, chemical or structural influences of substitutions of anions for $\mathrm{PO}_{4}$ have been also studied. Motisuke et al. ${ }^{6}$ prepared $\mathrm{Si}$-doped $\alpha$-TCP with a $\mathrm{Si} /(\mathrm{P}+\mathrm{Si})$ mol\% of 2.5 below $1200^{\circ} \mathrm{C}$. The dissolution of $\mathrm{AlPO}_{4}$ into TCP resulted in a remarkable chemical and structural stability of the $\beta$ structure, and no transition into $\alpha$-TCP even at $1300{ }^{\circ} \mathrm{C}^{7}$. Toriyama et al. ${ }^{8}$ reported that the mixed dissolution of $\mathrm{Al}_{2} \mathrm{O}_{3}$ and $\mathrm{SiO}_{2}$ into TCP 
resulted in the $\beta$ structure, e.g., no transition at $1200^{\circ} \mathrm{C}$, however the single dissolution of each of them did not stabilize the $\beta$ structure. Barnes et al. ${ }^{9}$ reported that $\mathrm{TCP}-\mathrm{Ca}_{2} \mathrm{SiO}_{4}$ solid solutions were hydrated to form a mixture of hydroxyapatite $\left(\mathrm{Ca}_{5}(\mathrm{OH})\left(\mathrm{PO}_{4}\right)_{3}\right.$, $\mathrm{Ap}), \mathrm{C}-\mathrm{S}-\mathrm{H}$ gel and $\mathrm{Ca}(\mathrm{OH})_{2}$, however the hydration activities were lower than that of pure $\alpha$-TCP. Berry et al. ${ }^{10}$ studied the reaction between gypsum $\left(\mathrm{CaSO}_{4} \cdot 2 \mathrm{H}_{2} \mathrm{O}, \mathrm{G}_{2 \mathrm{H}}\right)$ and brushite $\left(\mathrm{CaHPO}_{4} \cdot 2 \mathrm{H}_{2} \mathrm{O}\right)$ by thermogravimetric (TG) analysis and clarified that the reaction producing $\beta$-TCP and $\mathrm{SO}_{3}$ started at $800^{\circ} \mathrm{C}$ and completed at $950^{\circ} \mathrm{C}$, however did not mention the dissolution of $\mathrm{SO}_{4}$ into the $\beta$ structure. Marraha et al. ${ }^{11}$ reported the formation of $\mathrm{SO}_{4}$-dissolving $\beta$-TCP. It was performed by heating a mixture of $\mathrm{Ap}$ and $\left(\mathrm{NH}_{4}\right)_{2} \mathrm{SO}_{4}$ at temperatures from 1000 to $1100{ }^{\circ} \mathrm{C}$. The resulting $\beta$-TCP had IR absorption bands at 1150 and $1200 \mathrm{~cm}^{-1}$, and no band at $674 \mathrm{~cm}^{-1}$ of $\mathrm{SO}_{4}$ in pure anhydrous gypsum $\left(\mathrm{CaSO}_{4}, \mathrm{IIG}\right)$ and no bands at 945 and $970 \mathrm{~cm}^{-1}$ of $\mathrm{PO}_{4}$ in pure $\beta$-TCP. Trombe et al. ${ }^{12}$ reported also $\mathrm{SO}_{4}$-substituted $\beta$-TCP with specific absorptions at 1150 and $1200 \mathrm{~cm}^{-1}$, and without $674 \mathrm{~cm}^{-1}$ of $\mathrm{CaSO}_{4}, 945$ and 970 $\mathrm{cm}^{-1}$ of pure $\beta$-TCP. The solid solution reaction and chemical composition were proposed by the reaction, $\quad\left[\mathrm{Ca}_{21} \square_{3}\right]\left[\left(\mathrm{PO}_{4}\right)_{14} \square\right.$ 2] $+2 \mathrm{CaSO}_{4} \rightarrow\left[\mathrm{Ca}_{23} \square\right]\left[\left(\mathrm{PO}_{4}\right)_{14}\left(\mathrm{SO}_{4}\right)_{2}\right]$ at $1000-1100{ }^{\circ} \mathrm{C}$, where $\square$ is Ca-site vacancy existing originally in the $\beta$-TCP structure. Chabchoub et al. ${ }^{13}$ presented X-ray diffraction (XRD) and IR spectroscopic features of TCP- $-\mathrm{MSO}_{4}(\mathrm{M}=\mathrm{Sr}, \mathrm{Ba})$ solid solutions with the $\beta$-phase deficient compositions prepared at $1000{ }^{\circ} \mathrm{C}$. Supposing the stoichiometric replacement of $\mathrm{PO}_{4}$ by $\mathrm{SO}_{4}, \quad \mathrm{Ca}$-site deficiencies could be introduced as follows:

$$
\begin{aligned}
& 2 \mathrm{CaSO}_{4}\left(\text { in } \mathrm{Ca}_{3}\left(\mathrm{PO}_{4}\right)_{2}\right) \\
& \quad \rightarrow 2 \mathrm{Ca}{ }_{(\mathrm{Ca})}{ }^{\mathrm{x}}+\square_{(\mathrm{Ca})}{ }^{\prime \prime}+2 \mathrm{SO}_{4}(\mathrm{PO} 4)
\end{aligned}
$$

When such a reaction does not occur, the following simple reactions are written.

$$
\begin{aligned}
& 3 \mathrm{Ca}_{3}\left(\mathrm{PO}_{4}\right)_{2}+\mathrm{CaSO}_{4}+\mathrm{H}_{2} \mathrm{O}(\text { in air }) \\
& \quad \rightarrow 2 \mathrm{Ca}_{5}(\mathrm{OH})\left(\mathrm{PO}_{4}\right)_{3}+\mathrm{SO}_{3} \uparrow\left(1300^{\circ} \mathrm{C}\right) \\
& \mathrm{Ca}_{3}\left(\mathrm{PO}_{4}\right)_{2}+\mathrm{CaSO}_{4} \\
& \quad \rightarrow \mathrm{Ca}_{4}\left(\mathrm{PO}_{4}\right)_{2} \mathrm{O}+\mathrm{SO}_{3} \uparrow \quad\left(1400^{\circ} \mathrm{C}\right)
\end{aligned}
$$

In the present study, expecting the increases in hydration reactivity of TCP, synthetic $\beta$-TCP was heated with $\mathrm{G}_{2 \mathrm{H}}$ at high temperatures above $1200{ }^{\circ} \mathrm{C}$. The resulting products were characterized in detail.

\section{EXPERIMENTAL}

The starting materials used were reagent grades of $\mathrm{CaHPO}_{4} \cdot 2 \mathrm{H}_{2} \mathrm{O}, \mathrm{CaCO}_{3}$, and $\mathrm{G}_{2 \mathrm{H}}$. The first two materials were weighed in the stoichiometric ratio of the TCP composition, then added with $\mathrm{G}_{2 \mathrm{H}}$ at 1-10 mass\% corresponding to $1.8-18 \mathrm{~mol} \%$ in $\mathrm{G}_{2 \mathrm{H}} / \mathrm{TCP}$ ratio, then the mixtures were milled thoroughly using an agate mortar. Thus obtained mixtures were heated at $1300{ }^{\circ} \mathrm{C}$ (partially $1400{ }^{\circ} \mathrm{C}$ ), then cooled rapidly to room temperature, and then ground to a degree of passing through a 150 inch-mesh sieve (BET surface area estimated : $c a .1 .0 \mathrm{~m}^{2} / \mathrm{g}^{14}$ ). The resulting products were examined on the phase of TCP and whether or not $\mathrm{SO}_{4}$ ions dissolved in the TCP structure by using DTA (MAC SCIENCE, TG-DTA2000s), XRD (MAC SCIENCE, M03X-HF), FTIR (JASCO, FTIR-230) and EDX (HORIBA, EMAX-5770). The hydration reactivity and hardening runs were carried out under conditions : $0.5 \mathrm{~g}$ powdery sample / $50 \mathrm{ml} \mathrm{H}_{2} \mathrm{O}$ in a sealed vessel, $80^{\circ} \mathrm{C}$, without stirring. The resulting products 
sedimented in the bottom of the vessel were evaluated by XRD about reactivity and by touching the sediment by hand about hardening.

\section{RESULTS AND DISCUSSION}

\section{DTA}

When the solid-solution reaction of $\mathrm{G}_{2 \mathrm{H}}$ with TCP occurs as Eq. (1), the $\beta \rightarrow \alpha$ transition temperature must be influenced. FIGURE 1 shows DTA curves of $\beta$-TCP and a $\mathrm{G}_{2 \mathrm{H}^{-}}$added $\beta$-TCP. The $\beta \rightarrow \alpha$ temperature increased from 1198 to $1253^{\circ} \mathrm{C}$. In other words, a structural influence of $\mathrm{G}_{2 \mathrm{H}}$ on TCP was clear. The reversible endothermic and exothermic peaks around $1410-1430^{\circ} \mathrm{C}$ assigned to the $\alpha$ $\rightleftarrows \alpha^{\prime}$ transition was studied separately in detail by DTA and presented elsewhere ${ }^{15}$.

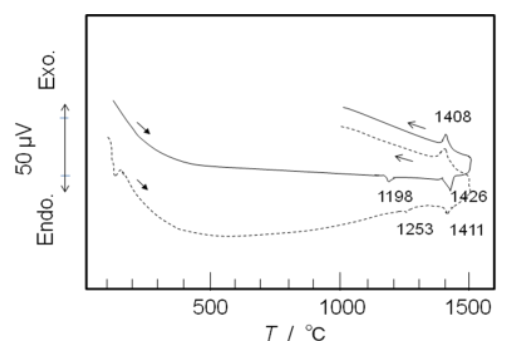

FIGURE 1 DTA curves of $\beta$-TCP (solid line) and $10 \mathrm{mass} \% \mathrm{G}_{2 \mathrm{H}}$-added $\beta$-TCP (broken line). (25.0mg sample, $25^{\circ} \mathrm{C} / \mathrm{min}$, in quiescent air)

\section{Structural characterization of products}

FIGURES 2 and 3 show XRD patterns and FTIR spectra of products quenched from $1300{ }^{\circ} \mathrm{C}$ in the system $\beta-\mathrm{TCP}-\mathrm{G}_{2 \mathrm{H}}$. The addition of $\mathrm{G}_{2 \mathrm{H}}$ tended to inhibit the $\beta \rightarrow \alpha$ transition, i.e., suggested the partial substitution of $\mathrm{SO}_{4}$ (ion radius $0.230 \mathrm{~nm}$ ) for $\mathrm{PO}_{4}(0.238 \mathrm{~nm})$ as written by Eq. (1). However, no XRD peak shifts of reaction products, i.e., $\alpha$-TCP, $\beta$-TCP, $\mathrm{Ap}$ and tetracalcium phosphate $\mathrm{Ca}_{4}\left(\mathrm{PO}_{4}\right)_{2} \mathrm{O}$ within an experimental error. And also, in the FTIR spectra, any clear changes among heating products with and without $\mathrm{G}_{2 \mathrm{H}}$, e.g., splitting peaks $\left(1150,1200 \mathrm{~cm}^{-1}\right)$ observed in the spectrum of $\mathrm{SO}_{4}$-substituted $\beta-\mathrm{TCP}^{13}$, were not recognized.

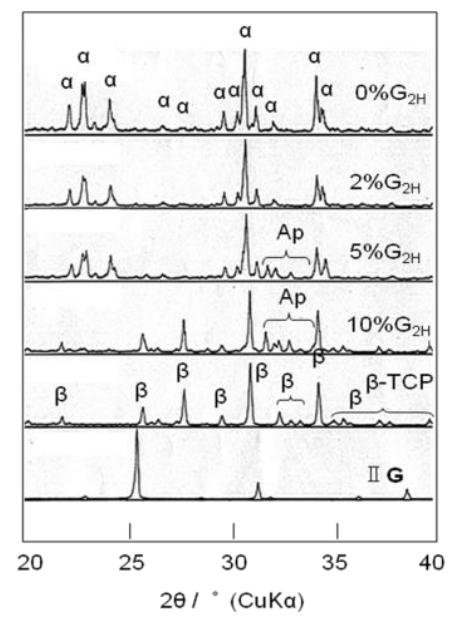

FIGURE 2 XRD patterns of products in the system $\beta-\mathrm{TCP}-\mathrm{G}_{2 \mathrm{H}}\left(1300^{\circ} \mathrm{C}-3 \mathrm{~h}\right.$, quenched $)$ and references (pure $\beta$-TCP and II G ( II $\mathrm{CaSO}_{4}$ ) heated at $1300{ }^{\circ} \mathrm{C}$ for $3 \mathrm{~h}$. $\alpha$ : $\alpha$-TCP, $\beta: \beta$-TCP, Ap:Hydroxyapatite

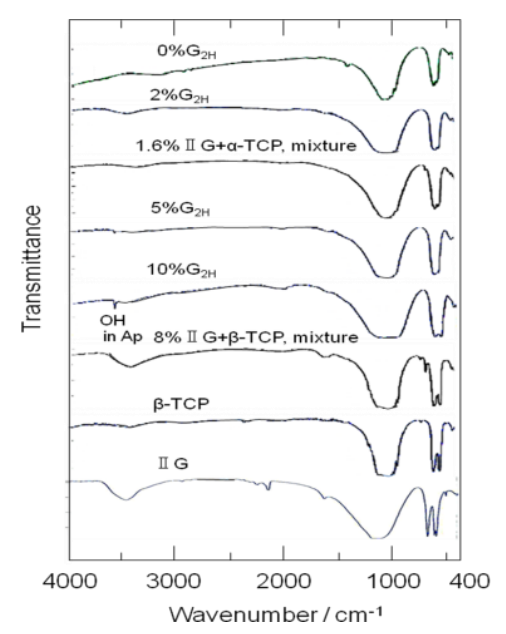

FIGURE 3 FTIR spectra of products in The system $\beta-\mathrm{TCP}-\mathrm{G}_{2 \mathrm{H}}\left(1300^{\circ} \mathrm{C}-3 \mathrm{~h}\right.$, quenched) and references ( $\beta-\mathrm{TCP}$, II G). 
In order to reconfirm such an inhibiting effect, an experiment using $\mathrm{CaCO}_{3}$ instead of $\mathrm{G}_{2 \mathrm{H}}$ was conducted. TABLE 1 summarized XRD phases of the resulting solid products at $1300^{\circ} \mathrm{C}$ and $1400^{\circ} \mathrm{C}$. The difference between the products in the systems $\beta-\mathrm{TCP}-\mathrm{G}_{2 \mathrm{H}}$ and $\beta-\mathrm{TCP}-\mathrm{CaCO}_{3}$ with the same $\mathrm{CaO}$ mol\% indicated the inhibition of $\mathrm{G}_{2 \mathrm{H}}$ to the transition of TCP from $\beta$ to $\alpha$. The presence of element $\mathrm{S}$ was also checked by EDX (FIGURE 4), however not detected.

TABLE 1 XRD phase of products in the system $\beta-\mathrm{TCP}-\mathrm{G}_{2 \mathrm{H}}$.

\begin{tabular}{|c|c|c|}
\hline \multirow{2}{*}{$\begin{array}{c}\mathrm{G}_{2 \mathrm{H}}+\beta-\mathrm{TCP} \\
\quad \text { mixture } \\
\mathrm{G}_{2 \mathrm{H}} / \mathrm{mass} \%(\mathrm{~mol} \%)\end{array}$} & \multicolumn{2}{|c|}{ XRD phase ${ }^{a}$ after heating } \\
\hline & $1300^{\circ} \mathrm{C}-3 \mathrm{~h}$ & $1400^{\circ} \mathrm{C}-3 \mathrm{~h}$ \\
\hline $0 \quad(0)$ & $\alpha \mathrm{T}$ & $\alpha \mathrm{T}$ \\
\hline $1.0 \quad(1.8)$ & $\alpha \mathrm{T}$ & -- \\
\hline $2.0 \quad(3.6)$ & $\alpha \mathrm{T}$ & -- \\
\hline $4.0 \quad(7.2)$ & $\alpha \mathrm{T} \gg>\beta \mathrm{T}, \mathrm{Ap}$ & -- \\
\hline $5.0 \quad(9.0)$ & $\alpha \mathrm{T}>\mathrm{A} p>\beta \mathrm{T}$ & $\alpha \mathrm{T}>\mathrm{Te}$ \\
\hline $6.0 \quad(10.8)$ & $\alpha \mathrm{T}, \beta \mathrm{T}, \mathrm{Ap}$ & $\alpha \mathrm{T}>\mathrm{Te}$ \\
\hline $10.0 \quad(18.0)$ & $\beta \mathrm{T}>\mathrm{Ap}$ & $\alpha \mathrm{T}, \beta \mathrm{T}>\mathrm{Te}$ \\
\hline $5.8^{b)}(18.0)$ & $\alpha \mathrm{T}, \mathrm{Ap}$ & -- \\
\hline
\end{tabular}

a) $\beta \mathrm{T}: \beta-\mathrm{TCP}, \alpha \mathrm{T}: \alpha-\mathrm{TCP}, \mathrm{Ap}: H y d r o x y a p a t i t e$, Te: Tetracalcium phosphate $\left(\mathrm{Ca}_{4}\left(\mathrm{PO}_{4}\right)_{2} \mathrm{O}\right)$

b) $\mathrm{CaCO}_{3}$ was added instead of $\mathrm{G}_{2 \mathrm{H}}$.

Consequently, the substitution itself of $\mathrm{SO}_{4}$ for $\mathrm{PO}_{4}$ could not directly detected, however the DTA curves showed clearly a structural influence suggesting the substitution.

\section{Hydration reactivity}

FIGURE 5 shows XRD patterns of products after the hydration run, and TABLE 2 summarized changes of the products. Formation degrees of Ap, which reflects the hydration reactivity, were in the order, pure $\alpha$-TCP $\ll \alpha$-TCP heated with $\mathrm{G}_{2 \mathrm{H}}$. This result suggested also the substitution of $\mathrm{SO}_{4}$ for $\mathrm{PO}_{4}$ as well as the above DTA

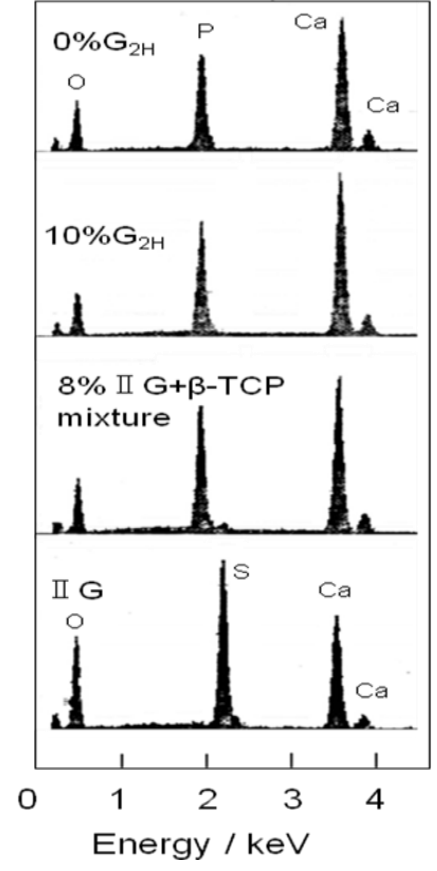

FIGURE 4 EDX spectra of products in the system $\beta-\mathrm{TCP}-\mathrm{G}_{2 \mathrm{H}}\left(1300^{\circ} \mathrm{C}-3 \mathrm{~h}\right.$, quenched $)$.

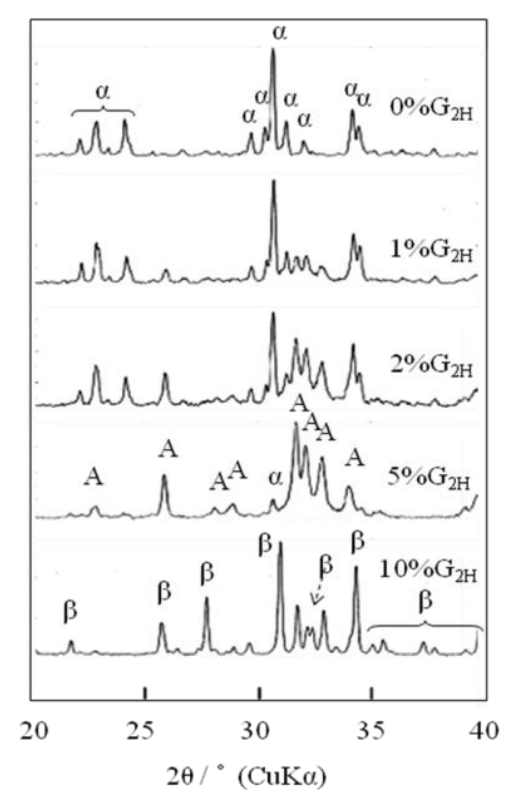

FIGURE 5 XRD patterns of products in the system $\beta-\mathrm{TCP}-\mathrm{G}_{2 \mathrm{H}}\left(1300^{\circ} \mathrm{C}-3 \mathrm{~h}\right.$, quenched) after the hydration run $\left(80^{\circ} \mathrm{C}-1 \mathrm{~h}\right.$, without stirring).

$\alpha: \alpha$-TCP, $\beta: \beta$-TCP, A:Hydroxyapatite 
TABLE 2 Hydration reactivity and hardening of products in the system $\beta-\mathrm{TCP}-\mathrm{G}_{2 \mathrm{H}}$.

\begin{tabular}{|c|c|c|c|c|c|}
\hline \multirow{3}{*}{$\begin{array}{c}\beta-\mathrm{TCP}+\mathrm{G}_{2 \mathrm{H}} \\
\text { mixture } \\
\mathrm{G}_{2 \mathrm{H}} / \operatorname{mass} \% \\
(\mathrm{~mol} \%)\end{array}$} & \multirow{3}{*}{$\begin{array}{c}\begin{array}{c}\text { Prepared } \\
\text { products } \\
\left(1300^{\circ} \mathrm{C}-3 \mathrm{~h}\right)\end{array} \\
\mathrm{XRD} \text { a) } \\
\end{array}$} & \multicolumn{4}{|c|}{$\begin{array}{l}\text { Hydration in } \mathrm{H}_{2} \mathrm{O} \text { at } 80^{\circ} \mathrm{C} \\
\text { without stirring }(0.5 \mathrm{~g} / 50 \mathrm{ml})\end{array}$} \\
\hline & & \multicolumn{2}{|c|}{ After lh } & \multicolumn{2}{|r|}{ After $3 \mathrm{~h}$} \\
\hline & & Hardening & $\mathrm{XRD}$ a) & Hardening & $\mathrm{XRD}$ a) \\
\hline $0 \quad(0)$ & $\alpha \mathrm{T}$ & $x$ & $\alpha \mathrm{T}$ & $x$ & $a \mathrm{~T}$ \\
\hline $1.0(1.8)$ & $a \mathrm{~T}$ & 0 & $\omega \mathrm{T} \gg \mathrm{Ap}$ & 0 & $\mathrm{Ap} \gg \gg \mathrm{T}, \alpha \mathrm{T}$ \\
\hline $2.0(3.6)$ & $\alpha \mathrm{T}$ & 0 & $\alpha \mathrm{T}, \mathrm{Ap}$ & 0 & $A p>>\beta T$ \\
\hline $3.0 \quad(5.4)$ & $\alpha \mathrm{T} \gg \gg \beta \mathrm{T}$ & 0 & Ap, $\alpha \mathbf{T}>\beta \mathbf{T}$ & -- & --- \\
\hline $4.0 \quad(7.2)$ & $\alpha \mathrm{T} \gg>\mathrm{TT}, \mathrm{Ap}$ & 0 & $A p>a T>\beta T$ & -- & --- \\
\hline $5.0(9.0)$ & $\alpha \mathrm{T}>\mathrm{Ap}>\beta \mathrm{T}$ & 0 & $A p>a T>\beta T$ & 0 & $A p \gg>T P \beta T$ \\
\hline $6.0(10.8)$ & $\alpha \mathrm{T}, \beta \mathrm{T}>\mathrm{Ap}$ & 0 & $\beta \mathrm{T}>\mathrm{Ap}, a \mathrm{~T}$ & -- & --- \\
\hline $10.0(18.0)$ & $\beta T>A p$ & $x$ & $\beta T>A p$ & $x$ & $\beta T>A p$ \\
\hline
\end{tabular}

a) $\beta \mathrm{T}: \beta-\mathrm{TCP}, \alpha \mathrm{T}: \alpha-\mathrm{TCP}, \mathrm{Ap}:$ Hydroxyapatite

\section{CONCLUSIONS}

The addition of gypsum $\left(\mathrm{CaSO}_{4} \cdot 2 \mathrm{H}_{2} \mathrm{O}\right)$ to tricalcium phosphate $\left(\mathrm{Ca}_{3}\left(\mathrm{PO}_{4}\right)_{2}, \mathrm{TCP}\right)$ tended to inhibit the transition of the low temperature form $\beta$ to the high temperature form $\alpha$ of TCP. However both the substitution of $\mathrm{SO}_{4}$ for $\mathrm{PO}_{4}$ and the presence of $\mathrm{S}$ were not detected directly. Increasing the amount of gypsum resulted in the formation of hydroxyapatite $\left(\mathrm{Ca}_{5}(\mathrm{OH})\left(\mathrm{PO}_{4}\right)_{3}\right)$ at $1300^{\circ} \mathrm{C}$ and tetracalcium phosphate $\left(\mathrm{Ca}_{4}\left(\mathrm{PO}_{4}\right)_{2} \mathrm{O}\right)$ at $1400{ }^{\circ} \mathrm{C}$. The hydration reactivity of $\alpha$-TCP prepared at $1300{ }^{\circ} \mathrm{C}$ was in the order, pure $\alpha-\mathrm{TCP} \ll$ $\alpha$-TCP heated with $\mathrm{G}_{2 \mathrm{H}}$.

\section{REFERENCES}

1. K.Yoshida, H.Hyuga, N.Kondo, H.Kita, M. Sasaki, M.Mitamura, K.Hashimoto, Y. Toda, J. Amer. Ceram. Soc., 89, 688 (2006).

2. R.G.Carrodeguas, A.H.De Aza, X.Turrillas, P.Pena, S.De Aza, J. Amer. Ceram. Soc., 91, 1281(2008).

3. K.Hashimoto, Y.Toda, S.Udagawa, T. Kanazawa, Inorg. Mater., 6, 285(1999).

4. K.Hashimoto, Y.Toda, T.Arakawa, T. Saotoh, T.Kanazawa, S.Udagawa, Inorg. Mater., 2, 171(1995).

5. H.Aoki, M.Akao, S.Nakamura, A.Ito, T. Otsuka, Rep. Inst. Med. Dent. Eng., 22, 23(1988).

6. M.Motisuke, R.G.Carrodeguas, C.A.C. Zavaglia, Key Eng. Mater., 361-363, 199(2008).

7. H.Monma, T.Kanazawa, Yogyo-Kyokai-Shi, 86, 46(1978).

8. M.Toriyama, S.Kawamura,Y.Ito,H.Nagae, I.Toyama, J. Ceram. Soc. Japan, 96, 837 (1988).

9. M.W.Barnes, M.Klimkiewicz, P.W.Brown, J. Amer. Ceram. Soc., 75, 1423(1992).

10. E.E.Berry, Biotechnol., J. appl. Chem., 22, 673(1972).

11. M.Marraha, J-C.Heughebaert, G.Montel, Ceram. Int., 9, 93(1983).

12. J.C.Trombe, J.Szilagyl, G.Montel, C.R. Acad. Sc. Paris, 283,199(1976).

13. S.Chabchoub, M.Dogguy, J. Therm. Anal., 39, 359(1993).

14.H.Monma, S.Ueno, Gypsum \& Lime, No.163, 6(1979).

15. H.Monma, T.Okura, H.Ogata,Y.Moriyoshi, Abstr. $20^{\text {th }}$ Annual Meeting of Inorganic Phosphorus Chemistry, Japan, 70(2010). 